\title{
CHOICE OF FORUM DALAM PENYELESAIAN SENGKETA PERBANKAN SYARIAH
}

\author{
Neni Sri Imaniyati dan Badruddin ${ }^{1}$
}

\begin{abstract}
Abstrak
UU No.3 of 2006 regarding Amendment of UU No.7 of 1989 regarding Religion Court (Peradilan Agama) give the additional authority to the Religion Court, for examine, decide, and resolute dispute Syaria banking. While UU No.21 of 2008 regarding Syaria Banking decides that a dispute in syaria banking can be resoluted at Religion Court also can be resoluted at General Court (Peradilan Umum). This of course can create a Choice of Forum. Therefore it needs to be examine what are the method and the dispute resolution type of syaria banking? And if the "Lex posteriorie derogate lex priorie" principle and "lex specialis derogate lex generalis" principle can be used in Choice of Forum resoluting a dispute in syaria banking? From the examination result can be determine that the method and the type of dispute resoluting of syaria banking according to UU No. 3 of 2006 and UU No.21 of 2008 can be used through the litigation process, in Religion Court and General Court. Besides through the litigation process also can be performed from the non-litigate process, discussion, banking mediation, through Basyarnas or other arbitrate institution and alternative dispute resolution with the regulation not against the syaria principal. The "lex posteriorie derogate lex priorie" principle and "the lex specialis derogate lex generalis" principle cannot be used in Choice of Forum resoluting a dispute in syaria banking.
\end{abstract}

Kata kunci: pilihan forum, penyelesaian sengketa, perbankan syariah

\section{Pendahuluan}

Secara prinsip penegakan hukum di Indonesia hanya dilakukan oleh kekuasaan kehakiman (judicial power) yang secara konstitusional lazim disebut badan yudikatif (Pasal 24 Undang-undang Dasar 1945). Undangundang No. 4 Tahun 2004 tentang Kekuasaan Kehakiman menyatakan bahwa kekuasaan kehakiman adalah kekuasaan negara yang merdeka untuk

${ }^{1}$ Kedua Penulis adalah Dosen Fakultas Hukum Universitas Islam Bandung. Alamat korespondensi: imaniyati@yahoo.com. 
menyelenggarakan peradilan guna menegakkan hukum dan keadilan. Undang-undang No.4 tahun 2004 pun secara tegas menyatakan bahwa yang berwenang dan berfungsi melaksanakan peradilan hanya badan-badan peradilan yang dibentuk berdasarkan undang-undang. Di luar itu tidak dibenarkan karena tidak memenuhi syarat formal dan official serta bertentangan dengan prinsip under the authority of law. ${ }^{2}$ Undang-undang No. 7 Tahun 1989 tentang Peradilan Agama menetapkan kewenangan Peradilan Agama yaitu memeriksa,memutus dan menyelesaikan perkara antara orangorang yang beragama Islam dan perkara perdata tertentu seputar perkawinan,kewarisan,wasiat,hibah,wakaf dan sedekah yang dilakukan berdasarkan hukum Islam. Dalam perkembangannya UU No. 3 tahun 2006 tentang perubahan atas UU No. 7 Tahun 1989 tentang Peradilan Agama, kewenangan Peradilan Agama telah memberikan tambahan kewenangan kepada Peradilan Agama yaitu memeriksa,memutus dan menyelesaikan perkara zakat,infaq dan ekonomi syariah.

UU No. 3 tahun 2006 menyatakan bahwa sengketa ekonomi syariah menjadi kewenangan Peradilan Agama secara mutlak. Undang-undang pun menyebutkan apa yang dimaksud dengan ekonomi syariah, yaitu perbuatan atau kegiatan usaha yang dilaksanakan menurut prinsip syariah, meliputi bank syariah,lembaga keuangan mikro syariah,asuransi syariah,reasuransi syariah,reksadana syariah,obligasi syariah,pegadaian syariah.

Berkaitan dengan perkembangan perbankan syariah di Indonesia, pada tahun 1998 eksistensi Bank Syariah telah dikukuhkan dengan dikeluarkannya UU No 10 Tahun 1998 tentang Perubahan UU No. 7 Tahun 1992 tentang Perbankan. Dalam undang-undang ini terdapat beberapa perubahan yang memberikan peluang yang lebih besar bagi pengembangan perbankan syariah di Indonesia. Undang-undang ini pun memberikan penegasan terhadap konsep perbankan Islam dengan mengubah penyebutan "Bank Berdasarkan Prinsip Bagi Hasil" pada Undang-Undang No. 7 Tahun 1992, menjadi "Bank Berdasarkan Prinsip Syariah". Juga terdapat penguatan kedudukan Hukum Islam bidang perikatan dalam tatanan hukum positif. ${ }^{3}$ Pasal 1 ayat (13) menyebutkan sebagai berikut:

Prinsip syariah adalah aturan perjanjian berdasarkan Hukum Islam antara bank dengan pihak lain untuk menyimpan dana

2 Dadan Mutaqin. Penyelesaian Sengketa Perbankan Syariah di Luar lembaga Peradilan, Varia Peradilan No. 26 (Januari 2008),Ikahi Jakarta: 57 09-2005,5.

${ }^{3}$ Peri Umar Farouk, Sejarah Hukum Perbankan Syariah di Indonesia, download 04- 
dan atau pembiayaan kegiatan usaha, atau kegiatan lainnya yang dinyatakan sesuai dengan syariah, antara lain, pembiayaan berdasarkan prinsip bagi hasil (mudharabah), pembiayaan berdasarkan prinsip penyertaan modal (musyarakah), prinsip jual-beli barang dengan memperoleh keuntungan (murabahah), atau pembiayaan barang modal berdasarkan prinsip sewa murni tanpa pilihan (ijarah), atau dengan adanya pilihan pemindahan kepemilikan atas barang yang disewa dari pihak bank oleh pihak lain (ijarah wa Iqtina').

Masalah yang diatur undang-undang ini selain berupa penegasan terhadap eksistensi perbankan Islam di Indonesia juga menyangkut kelembagaan dan operasional bank Islam. Secara keseluruhan permasalahan hukum tersebut antara lain meliputi:

1. macam bank syariah;

2. pendirian bank syariah;

3. konversi bank konvensional menjadi bank syariah;

4. pembukaan Kantor Cabang, yang meliputi sisi keuangan dan modal kerja;

5. badan Pengawas Syariah dan Dewan Syariah Nasional (DPS), yang menyangkut mengenai fungsi DPS sebagai Penasihat, Mediator, dan Perwakilan;

6. kegiatan usaha dan produk-produk bank syariah;

7. pengawasan Bank Indonesia terhadap bank syariah;

8. sanksi-sanksi pidana dan administratif.

Pemberlakuan Undang-Undang No. 10 Tahun 1998 ini merupakan momen pengembangan perbankan syariah di Indonesia. Undang-undang tersebut membuka kesempatan untuk pengembangan jaringan perbankan syariah, antara lain melalui izin pembukaan Kantor Cabang Syariah (KCS) oleh bank konvensional. Dengan kata lain, bank konvensional dapat melakukan kegiatan usaha berdasarkan prinsip syariah. Landasan dan kepastian hukum yang kuat bagi para pelaku bisnis serta masyarakat luas ini meliputi:

a. Pengaturan aspek kelembagaan dan kegiatan usaha dan Bank Islam sebagaimana yang diamanatkan dalam Pasal 1 ayat 3 UndangUndang No. 10 Tahun 1998. Pasal tersebut menjelaskan, bahwa Bank Umum dapat memilih untuk melakukan kegiatan usaha berdasarkan sistem konvensional atau berdasarkan prinsip syariah atau melakukan kedua kegiatan tersebut. Dalam hal bank umum melakukan kegiatan usaha berdasarkan syariah, maka kegiatan 
tersebut dilakukan dengan membuka satuan kerja dan kantor cabang khusus, yaitu Unit Usaha Syariah dan Kantor Cabang Syariah. Sedangkan, BPR harus memilih kegiatan usaha berdasarkan prinsip syariah saja, atau berdasarkan sistem konvensional saja.

b. Bank umum konvensional yang akan membuka kantor cabang syariah wajib melaksanakan:

1) Pembentukan Unit Usaha Syariah (UUS);

2) Memiliki Dewan Pengawas Syariah (DPS) yang ditempatkan oleh Dewan Syariah Nasional (DSN); dan

3) Menyediakan modal kerja yang disisihkan oleh bank dalam suatu rekening tersendiri atas nama UUS yang dapat digunakan untuk membayar biaya kantor dan izin-izin berkaitan dengan kegiatan operasional maupun nonoperasional Kantor Cabang Syariah (KCS).

Namun demikian, pada periode Undang-Undang No. 10 Tahun 1998 ini juga dapat dilihat adanya beberapa permasalahan hukum yang masih harus diatur lebih lanjut dalam pengaturan tersendiri yang perlu dipertimbangkan dalam regulasi perbankan nasional.

Pada tanggal 16 Juli 2008 telah disahkan Undang-undang No 21 Tahun 2008 tentang Perbankan Syariah. Undang-undang ini lebih mengukuhkan keberadaan perbankan syriah di Indonesia. Undang-undang No. 21 tahun 2008 mengatur lebih spesifik perbankan syariah, termasuk tentang penyelesaian sengketa yang tidak diatur dalam Undang-undang No 10 tahun 1998. Namun berbeda dengan yang diatur dalam Undang-undang No. 3 tahun 2006, menurut Pasal 55 UU No. 21 tahun 2008 penyelesaian sengketa yang terjadi pada perbankan syariah tidak mutlak menjadi kewenangan Peradilan Agama. Penyelesaian sengketa perbankan syariah menurut undang-undang ini tergantung pada perjanjian yang dibuat oleh para pihak. Para pihak yang terlibat pada perbankan syariah ketika membuat akad dapat menunjuk badan lain di luar Peradilan Agama untuk penyelesaian sengketa yang terjadi di antara mereka,lembaga yang ditunjuk itulah yang berwenang menyelesaikan sengketa jika terjadi sengketa.

Dengan demikian UU No. 21 tahun 2008 tentang Perbankan Syariah telah mereduksi kewenangan Peradilina Agama dalam menyelesaikan sengketa perbankan syariah seperti yang diatur dalam undang-undang No. 3 tahun 2006.

Tulisan ini akan mengkaji tentang penyelesaian sengketa perbankan syariah yang difokuskan pada dua permasalahan, yaitu tentang bagaimana bentuk dan metoda penyelesaian sengketa perbankan syariah menurut UU No. 3 tahun 2006 dan UU No. 21 tahun 2008 ? dan apakah asas lex 
posteriore derogat lex priori dan lex specialis derogat lex generalis dapat digunakan dalam choice of forum penyelesaian sengketa perbankan syariah?

\section{Pembahasan}

\section{A. Metoda dan Bentuk Penyelesaian Sengketa Perbankan Syariah menurut UU No 3 Tahun 2006 dan UU No. 21 Tahun 2008.}

Metoda penyelesaian sengketa perdata perbankan syariah yang diatur dalam UU No. 3 Tahun 2006, Peraturan Bank Indonesia (PBI) No. 9/19/PBI/2007 tentang Pelaksanaan Prinsip Syariah dalam Kegiatan Penghimpunan dan Penyaluran Dana serta Pelayanan Jasa Bank Syariah, dan UU No. 21 Tahun 2008 dapat dilakukan melalui dua jalur, pertama, melalui proses di luar peradilan (nonlitigasi), dan kedua yaitu melalui proses peradilan litigasi). Kedua undang-undang dan PBI tersebut sejalan dengan Pasal 3 UU No. 4 tahun 2004 tentang Kekuasaan Kehakiman yang menyatakan bahwa tidak tertutup kemungkinan penyelesaian sengketa perkara di luar peradilan negara melalui perdamaian dan arbitrase.

Proses penyelesaian melalui jalur nonlitigasi dapat dilihat dalam ketentuan Pasal 55 ayat (2) UU No.21 tahun 2008 yang menyebutkan bahwa jika para pihak telah memperjanjikan penyelesaian sengketa selain melalui peradilan agama, penyelesaian dapat dilakukan sesuai dengan isi akad. Penjelasan pasal tersebut menyatakan bahwa yang dimaksud dengan penyelesaian sengketa dilakukan sesuai dengan isi akad, yaitu penyelesaian yang dilakukan melalui upaya musyawarah mediasi perbankan,badan arbitrase syariah nasional (Basyarnas) atau lembaga arbitrase lain dan/atau melalui pengadilan dalam lingkungan peradilan umum.

Ketentuan tersebut tidak jauh berbeda dengan isi Pasal 4 Peraturan Bank Indonesia (PBI) No. 9/19/PBI/2007. Namun dalam PBI tidak disebutkan badan peradilan tertentu, sedangkan dalam penjelasan Pasal 55 ayat (2) UU No. 21 tahun 2008 disebutkan badan peradilan umum.

Berkaitan dengan jalur nonlitigasi Undang-Undang No. 3 tahun 2006 dan UU No. 21 tahun 2008 tidak mengatur secara rinci. Untuk itu prosedur perdamaian dan arbitrase harus merujuk kepada undangundang lain dalam hal ini adalah UU No. No. 30 tahun 1999 tentang Arbitrase dan Alternatif Penyelesaian Sengketa. Proses penyelesaian sengketa perbankan syariah yang dimungkinkan pelaksanaannya 
dalam UU No. 30 tahun 1999 tersebut adalah melalui tahapan konsultasi,negosiasi,mediasi, konsultasi dan arbitrase.

Sebenarnya banyak metode/bentuk penyelesaian sengketa yang dapat dilakukan. Namun alternatif penyelesaian sengketa (Alternatif Dispute Resolution/ADR) yang tertera dalam UU No.30 tahun 1999, yakni konsultasi,negosiasi,mediasi,konsiliasi,pemberian nasihat hukum/ahli, dan arbitrase. Berbeda dengan arbitrase, pembahasan tentang alternatif penyelesaian sengketa dalam undang-undang tersebut hanya dituangkan dalam satu pasal, yaitu Pasal 6. Pasal ini pun tidak memberikan keterangan yang lebih rinci tentang konsultasi,negosiasi,mediasi,dan konsiliasi.

Untuk itu batasan konsultasi,negosiasi,mediasi,dan konsiliasi akan dikaji menurut kamus bahasa dan pendapat ahli.

Berdasarkan Kamus Bahasa Indonesia ${ }^{4}$, konsultasi adalah minta nasihat;mencari nasihat;2.memberi nasihat,keterangan dan sebagainya. Negosiasi bisa memiliki dua arti. Arti pertama adalah proses tawar menawar dengan jalan berunding untuk memberi atau menerima guna mencapai kesepakatan bersama antara satu pihak (kelompok atau organisasi) dan pihak (kelompok atau organisasi) yang lain;kedua : Penyelesaian sengketa secara damai melalui perundingan antara pihakpihak yang bersengketa. Mediasi yaitu proses pengikutsertaan pihak ketiga dalam penyelesaian suatu perselisihan sebagai penasihat, mediator: perantara (penghubung,penengah) bagi pihak-pihak yang bersengketa. Konsiliasi adalah usaha mempertemukan keinginan pihak yang berselisih untuk mencapai persetujuan dan menyelesaikan perselisihan.

Mengenai istilah negosiasi, dalam bahasa sehari hari dikenal dengan istilah berunding atau bermusyawarah.Menurut Joni Emerzon ${ }^{5}$ negosiasi dapat diartikan sebagai upaya penyelesaian sengketa para pihak tanpa melalui proses peradilan dengan tujuan mencapai kesepakatan bersama atas dasar kerjasama yang harmonis dan kreatif. Menurutnya para pihak berhadapan langsung secara seksama dalam mendiskusikan permasalahan yang dihadapi secara kooperatif dan saling terbuka.

${ }^{4}$ Departemen Pendidikan dan Kebudayakan, "Kamus Besar Bahasa Indonesia", Edisi ketiga (Jakarta: Balai Pustaka, 2001).

${ }^{5}$ Joni Emerzon, "Alternatif Penyelesaian Sengketa di Luar Pengadilan", (Jakarta: Gramedia Pustaka Utama), hal. 44. 
M. Marwan dan Jimmy P. ${ }^{6}$ memberikan batasan tentang konsultasi,negosiasi,mediasi,dan konsiliasi. Menurutnya Konsultasi adalah permohonan nasihat atau pendapat untuk penyelesaian suatu sengketa secara kekeluargaan yang dilakukan oleh para pihak kepada pihak ketiga. Negosiasi adalah proses tawar menawar dengan jalan berunding antara para pihak yang bersengketa untuk mencapai kesepakatan bersama. Mediasi adalah suatu proses penyelesaian sengketa secara damai yang melibatkan bantuan pihak ketiga untuk memberikan solusi yang dapat diterima pihak-pihak yang bersengketa;pengikutsertaan pihak ketiga dalam penyelesaian sengketa antara dua pihak. Sementara batasan Konsiliasi dikemukakan oleh Huala Adolf ${ }^{7}$ yang dikutip dari Opponheim, yaitu proses penyelesaian sengketa dengan menyerahkannya kepada suatu komisi orang-orang yang bertugas untuk menguraikan/menjelaskan fakta-fakta dan( biasanya setelah menmdengar para pihak dan mengupayakan agar mereka mencapai suatu kesepakatan), membuat usulan-usulan untuk suatu penyelesaian,namun keputusan tersebut tidak mengikat.

Metoda penyelesaian sengketa selain melalui konsultasi, negosiasi, mediasi,dan konsiliasi,UU No 30 tahun 1999 menetapkan pula bentuk lain, yaitu penilaian para ahli dan arbitrase. Arbitrase berasal dari bahasa Inggris arbitration, yang artinya perwasitan, mengadili, mengambil keputusan sesudah mendengar kedua belah pihak. $^{8}$

Menurut Subekti" arbitrase adalah "Penyelesaian atau pemutusan sengketa oleh seorang hakim atau para hakim berdasarkan persetujuan bahwa para pihak akan tunduk pada atau menaati keputusan yang diberikan oleh hakim atau para hakim yang mereka pilih atau tunjuk".

Menurut Moch. Basarah ${ }^{10}$ keputusan yang dikeluarkan arbitrase bersifat final dan mengikat para pihak,maka dalam kaitannya dengan sifat putusan tersebut para pihak harus menerimanya secara sukarela.

"M. Marwan dan Jimmy.P. "Kamus Hukum", (Dictionary of Law Complete Edition), (Surabaya: Reality Publisher, 2009), hal. 19.

${ }^{7}$ Huala Adolf dan A. Chandrawulan, "Masalah-masalah Hukum dalam Perdagangan International", (Jakarta: PT.Raja Grafindo Persada, 1994), hal. 186.

${ }^{8}$ John M.Echols dan Hassan Shadily, "Kamus Inggris Indonesia", (An EnglishIndonesia Dictionary), (Jakarta PT. Gramedia, 2005), hal. 377.

${ }^{9}$ R.Subekti, "Arbitrase Perdagangan", (Bandung: Binacipta,1992), hal. 1. 
Sedangkan menurut Pasal 1 UU No. 30 tahun 1999, arbitrase adalah cara penyelesaian suatu sengketa perdata di luar peradilan umum yang didasarkan pada perjanjian arbitrase yang dibuat secara tertulis oleh para pihak yang bersengketa.

$\mathrm{Di}$ Indonesia terdapat beberapa lembaga arbitrase untuk menyelesaikan berbagai sengketa bisnis, antara lain: Badan Arbitrase Nasional Indonesia (BANI),Badan Arbitrase Muamalat Indonesia (BAMUI) yang kemudian berganti nama menjadi Badan Arbitrase Syariah Nasional (BASYARNAS).

Proses penyelesaian sengketa melalui cara-cara tersebut di atas (alternatif penyelelesaian sengketa) sejalan dengan firman Allah SWT dan sangat dianjurkan. Hal ini terdapat dalam Al Qur'an, antara lain:

1. Q.S. Asy Syuura ayat 38, yang artinya :

Dan (bagi) orang-orang yang nerima(mematuhi seruan tuhannya dan mendirikan shalat, sedang urusan mereka (diputuskan) dengan musyawarah antara mereka; dan mereka menafkahkan sebagian dari rizki yang Kami berikan kepada mereka.

2. Q.S. Ali Imran (3) Ayat 159 yang artinya :

dan bermusyawarahlah dengan mereka dalam urusan itu.....

3. Q.S. An Nisa (4) ayat 35 yang artinya :

Dan jika kamu khawatirkan ada persengketaan antara keduanya, maka kirimlah seorang hakam.

4. Q.S. An Nisa (4) ayat 128 yang artinya: dan perdamaian itu lebih baik.

Dari uraian di atas, tampaklah bahwa alternatif penyelesaian sengketa perbankan syariah dimungkinkan menurut UU No. 3 tahun 2006 dan menurut UU No. 21 Tahun 2008

Adapun bentuk-bentuk penyelesaian sengketanya baik menurut UU No 21 tahun 2008 maupun UU No 30 tahun 1999 dapat dilakukan melalui konsultasi,negosiasi,mediasi,dan konsiliasi,pendapat tenaga ahli dan arbitrase. Alternatif penyelesaian sengketa seperti ini sangat dianjurkan dalam hukum Islam.

${ }^{10}$ Moch.Basarah, "Mengenal Arbitrase Nasional dan Internasional", (Fakultas Hukum, Unisba, Bandung, 2008), hal. 5-6. 


\section{B. Choice of Forum dalam Penyelesaian Sengketa Perbankan Syariah dihubungkan dengan asas lex posteriori derogat lex priori dan asas lex spesialis derogat lex generalis}

Seperti telah diuraikan pada bagian pendahuluan, bahwa di Negara Republik Indonesia penegakan hukum untuk menyelesaikan suatu sengketa hanya dilakukan oleh kekuasaan kehakiman (judicial power) yang secara konstitusional lazim disebut badan yudikatif. Badan yudikatif ini bernaung di bawah kekuasaan kehakiman yang berpuncak di Mahkamah Agung.

Undang-undang Kekuasaan Kehakiman menetapkan badan-badan peradilan tersebut, yaitu Peradilan Umum, Peradilan Agama,Peradilan Militer, dan Peradilan Tata Usaha Negara. Keempat badan peradilan tersebut memiliki tugas pokok untuk menerima,memeriksa dan mengadili serta menyelesaikan setiap perkara yang diajukan kepadanya. Dengan demikian secara konstitusional yang memiliki syarat formal dan official penyelenggaraan kekuasaan kehakiman hanyalah keempat lingkungan badan peradilan tersebut.

Kompetensi absolut keempat badan peradilan tersebut telah diatur dalam undang-undang sebagai berikut :

1. Kompetensi absolut Peradilan Umum diatur dalam Pasal 50 dan 51 Undang-undang No.2 tahun 1986 terakhir diubah dengan Undang-undang No. 3 Tahun 2008 tentang Peradilan Umum, yaitu memeriksa,mengadili dan menyelesaikan perkara pidana dan perdata.

2. Kompetensi absolut Peradilan Agama diatur dalam Pasal 49 Undang-undang No.3 Tahun 2006 tentang Perubahan atas undngundang No.7 Tahun 1989 tentang Peradilan Agama, yaitu khusus memeriksa,memutus, dan menyelesaikan perkara tertentu antara orang-orang yang beragama Islam di bidang :

a. Perkawinan;

b. kewarisan (meliputi wasiat dan hibah);

c. Zakat,wakaf,infaq,dan shadaqah; dan

d. Ekonomi syariah; bank syariah,lembaga keuangan mikro syariah, asuransi syariah,reasuransi syariah,reksadana syariah, obligasi syariah,surat berharga berjangka syariah, dana pensiun lembaga keuangan syariah, dan bisnis syariah).

3. Kompetensi absolut Peradilan Tata Usaha Negara diatur dalam Pasal 47 Undang-undang No. 5 tahun 1986 terakhir diubah dengan Undang-undang No. 9 tahun 2004 tentang Peradilan Tata 
Usaha Negara,yaitu khusus mengadili sengketa Tata Usaha Negara.

4. Kompetensi Peradilan Militer diatur dalam Pasal 40 Undangundang No. 31 tahun 1997 tentang Peradilan Militer, yaitu khusus mengadili perkara pidana yang terdakwanya terdiri dari anggota militer.

Kewenangan Peradilan Agama dalam penyelesaian sengketa ekonomi syariah mulai diatur seiring dengan perkembangan ekonomi syariah di Indonesia. Hal ini terlihat dari undang-undang yang mengatur Peradilan Agama. UU No. 7 tahun 1989 tentang Peradilan Agama tidak mengatur tentang kewenangan peradilan Agama dalam penyelesaian sengketa ekonomi syariah.Mulai tahun 1990-an muncul lembaga lembaga keuangan syariah di Indonesia dan semakin marak perkembangannya dalam dekade terakhir. Untuk itu diperlukan pengaturan dan penegasan lembaga apa yang diberi kewenangan untuk menyelesaikan sengketa jika terjadi sengketa dalam ekonomi syariah.

$\mathrm{Hal}$ ini sangat diperlukan mengingat lembaga keuangan syariah dalam operasionalnya menggunakan akad yang lahir dari sistem eknomi syariah sehingga diperlukan konsistensi pelaksanaan ekonomi syariah termasuk dalam penyelesaian sengketa.

Dengan melihat uraian di atas, tampak bahwa dengan UU No. 3 Tahun 2006 kewenangan Peradilan Agama menjadi semakin luas dibandingkan dengan apa yang telah diatur dalam UU No. 7 Tahun 1989. Wildan Suyuti. ${ }^{11}$ mengemukakan bahwa UU No.3 tahun 2006 membawa perubahan penting di lingkungan Peradilan Agama. Undang-undang ini lahir dari tuntutan sosial di tengah maraknya pasar transaksi berdasarkan praktik ekonomi syariah. Selain kewenangan lama seperti perkawinan, waris, dan wakaf,kini hakim agama dibebani tanggung jawab baru mengadili perkara-perkara ekonomi syariah.

Pasal 50 UU No. 7 tahun 1989 diubah dengan UU No. 3 tahun 2006 menjadi dua ayat. Pasal ini menetapkan:

1. Dalam hal terjadi sengketa hak milik atau sengketa lain dalam perkara yang menjadi kewenangan Peradilan Agama, khusus mengenai objek sengketa tersebut harus diputus terlebih dahulu oleh peradilan dalam lingkungan Peradilan Umum.

${ }^{11}$ Wildan Suyuti, "Kapita Selekta Perbankan Syariah Menyongsong Berlakunya UU No.3 tahun 2006 tentang Perubahan UU No.7 Tahun 1989", (Pusdiklat Teknis Peradilan Balitbang Diklat Kumdil MA-RI, Jakarta, 2008), hal. 9. 
2. Apabila terjadi sengketa hak milik yang subjek hukumnya orang-orang yang beragama Islam, objek sengketa tersebut diputuskan oleh Peradina Agama bersama-sama perkara yang sedang diperiksa.

Undang-undang tersebut pun menetapkan bahwa sengketa perbankan syariah di bidang perdata menjadi kewenangan Peradilan Agama. Sedangkan sengketa perbankan syariah di bidang pidana dan tata usaha negara tidak termasuk dalam jangkauan kewenangan absolut lingkungan Peradilan Agama.

Berkaitan dengan kewenangan penyelesaian sengketa perbankan syariah menurut UU No 21 Tahun 2008 tentang Perbankan Syariah terdapat dalam Pasal 55 ayat (1). Pasal ini menetapkan bahwa penyelesaian sengketa perbankan syariah dilakukan oleh pengadilan dalam lingkungan Peradilan Agama. Selanjutnya ayat (2) Pasal 55 tersebut menetapkan bahwa dalam hal para pihak telah memperjanjikan penyelesaian sengketa selain melalui peradilan agama, penyelesaian sengketa dapat dilakukan sesuai dengan isi akad, dengan syarat yang diatur dalam ayat (3), yaitu penyelesaian sengketa tersebut tidak boleh bertentangan dengan prinsip syariah.

Dengan melihat ketentuan di atas, tampak bahwa penyelesaian sengketa perbankan syariah dapat dilakukan melalui proses peradilan dan melalui proses di luar peradilan. Di luar proses peradilan sengketa diselesaikan melalui musyawarah,mediasi perbankan, dan Basyarnas atau arbitrase lain. Adapun penyelesaian sengketa melalui peradilan dapat dilakukan oleh badan Peradilan Agama atau Peradilan Umum. Karena adanya beberapa pilihan ini maka peradilan agama tidak memiliki kompetensi absolut dalam penyelesaian sengketa perbankan syariah seperti halnya yang diatur dalam UU No 3 Tahun 2006.

Dengan adanya dua ketentuan yang berbeda ini menimbulkan permasalahan apakah dimungkinkan adanya dua form (choice of forum) untuk menyelesaikan sengketa untuk suatu hukum substantif yang sama dan subjek hukum yang sama?

Berkaitan dengan choice of forum ini ada dua pendapat, ada pendapat yang setuju ada pula yang tidak setuju. Pendapat yang setuju argumentasinya didasarkan pada asas kebebasan berkontrak dalam perjanjian. Dalam hukum perjanjian yang diatur dalam KUH Perdata berlaku asas kebebasan berkontrak (freedom of contract). Berdasarkan asas kebebasan berkontrak para pihak bebas memperjanjikan apa saja yang dikehendaki oleh mereka sebagai isi perjanjian (syarat-syarat dan ketentuan-ketentuan dari perjanjian itu), sepanjang,seperti telah dikemukakan di atas isi perjanjian itu tidak bertentangan dengan 
undang-undang,dengan kepatutan dan ketertiban umum. Remy Syahdaeni ${ }^{12}$ menyatakan bahwa asas kebebasan berkontrak menurut hukum perjanjian Indonesia meliputi ruang lingkup sebagai berikut:

a. Kebebasan untuk membuat atau tidak membuat perjanjian;

b. Kebebasan untuk memilih pihak dengan siapa ia ingin membuat perjanjian;

c. Kebebasan untuk menentukan atau memilih causa dari perjanjian yang akan dibuatnya;

d. Kebebasan untuk menentukan objek perjanjian;

e. Kebebasan untuk menentukan bentuk suatu perjanjian;

f. Kebebasan untuk menerima atau menyimpangi ketentuan undang-undang yang bersifat opsional (aanvullend optional).

Senada dengan pendapat di atas Fathurrahman Jamil ${ }^{13}$ mengatakan bahwa pihak-pihak yang melakukan akad mempunyai kebebasan untuk membuat perjanjian (fredom of making contract) baik dari segi yang diperjanjikan (objek perjanjian) maupun menentukan persyaratan-persyaratan lain, termasuk menetapkan cara-cara penyelesaian apabila terjadi sengketa.Kebebasan menentukan syarat ini dibenarkan sepanjang tidak bertentangan dengan ketentuan syariat Islam.

Menurut Salim H.S ${ }^{14}$ Pasal 1338 KUH Perdata ayat (1) menyebutkan bahwa semua perjanjian yang dibuat secara sah berlaku sebagai undang-undang bagai mereka yang membuatnya.Kata semua dipahami mengandung asas kebebasan berkontrak,yaitu suatu asas yang memberikan kebebasan kepada para pihak untuk:

a. Membuat atau tidak membuat perjanjian;

b. Mengadakan perjanjian dengan siapa pun

c. Menentukan isi perjanjian, pelaksanaan, dan persyaratannya,dan

d. Menentukan bentuk perjanjian,yaitu secara tertulis atau lisan.

${ }^{12}$ Remy Syahdaeni, "Kebebasan Berkontrak dan perlindungan yang Seimbang bagi Para Pihak dalam Perjanjian Kredit Bank di Indonesia",, (Institut Bankir Indonesia, Jakarta, 1993), hal. 47.

${ }^{13}$ Mariam Darus Badrulzaman, "Kompilasi Hukum Perikatan", (Bandung: Citra Aditya Bhakti, 2001), hal. 249.

${ }^{14}$ Salim H.S., "Hukum Kontrak: Teori dan Teknik Penyusunan Kontrak", (Jakarta: Sinar Grafika, 2004), hal. 9. 
Dari uraian di atas, tampaklah bahwa asas kebabasan berkontrak memberikan kebebasan kepada para pihak untuk menentukan syarat dan isi perjanjian termasuk cara penyelesaian sengketa apakah akan melalui proses litigasi maupun nonlitigasi. Proses melalui litigasi pun dapat dipilih oleh para pihak apakah akan memilih penyelesaian di lingkungan Peradilan Umum atau Peradilan Agama.

Munir Fuady ${ }^{15}$ mengemukakan beberapa keuntungan choice of forum dalam praktik penyusunan kontrak, yaitu:

a. Pengadilan tersebut lebih mengetahui hukum yang berlaku jika dipilih pengadilan yang terletak di tempat/negara yang juga dipilih hukumnya.

b. Pengadilan tersebut lebih mengetahui kasus yang bersangkutan jika yang dipilih adalah pengadilan tempat terjadinya kasus atau tempat dilaksanakannya kontrak tersebut.

c. Bahwa pengadilan tersebut dan para pihak lebih banyak akses ke alat bukti,termasuk alat bukti saksi jika yang dipilih adalah pengadilan tempat terjadinya kasus atau tempat dilaksankannya kontrak tersebut.

Pendapat yang tidak setuju dengan choice of forum ( sengketa perdata perbankan syariah diselesaikan di peradilan umum dan peradilan agama), yaitu Mariana Sutadi ${ }^{16}$ yang mengatakan bahwa perjanjian yang menyebutkan penyelesaian sengketa perdata perbankan syariah dilakukan oleh badan peradilan umum harus dinyatakan batal demi hukum karena bertentangan dengan undangundang.

Selanjutnya jika choice of forum dihubungkan dengan dua asas berlakunya perundang-undangan, yaitu asas hukum yang baru menghapuskan hukum yang lama dan asas hukum yang khusus mengenyampingkan hukum yang umum, kedua asas ini tidak dapat digunakan untuk mengkaji UU No. 3 tahun 2006 dan UU No. 21 tahun 2008.

Asas hukum yang baru ( UU No. 21 Tahun 2008 ) menghapuskan hukum lama ( UU No. 3 Tahun 2006 ) tidak dapat diberlakukan karena

${ }^{15}$ Munir Fuady, "Hukum Kontrak dari Sudut Pandang Hukum Bisnis", (Bandung: Citra Aditya Bakti, 2007), hal. 147.

${ }^{16}$ Mariana Sutadi, "Pendalaman Materi Mediasi di Pengadilan", Bandung, 22 Nopember 2008. 
kedua undang-undang ini mengatur hal yang berbeda, UU No 3 Tahun 2006 mengatur tentang Peradilan Agama sedangkan UU No. 21 Tahun 2008 mengatur tentang Perbankan Syariah. Salah satu syarat yang harus dipenuhi oleh asas hukum yang baru mengenyampingkan hukum yang lama adalah harus dalam regim hukum yang sama, misalnya sama-sama dalam bidang keperdataan, sama-sama dalam bidang peradilan. Asas ini tidak dapat diberlakukan pada rezim hukum yang berbeda.Sengketa perbankan syariah yang menerapkan hukum substantif yang sama dan subjek hukum yang sama tidak semestinya ada forum yang berbeda yang bebas dipilih oleh yang mengajukan sengketa.

Menurut Abdul Gafur Anshori ${ }^{17}$ penyelesaian sengketa di bidang perbankan syariah diselesaikan melalui peradilan umum berpotensi menimbulkan konflik antar dua lingkungan peradilan yang ada.

Selanjutnya jika dikaji dari asas hukum lex specialis derogat lex generalis ( hukum yang khusus mengenyampingkan hukum yang umum). Asas ini tidak dapat digunakan dalam masalah ini karena dua undang-undang tadi ( UU No. 3 Tahun 2006 dan UU No. 21 tahun 2008) tidak dapat ditentukan undang-undang yang berlaku umum dan undang-undang yang berlaku khusus. Hal ini berbeda dengan UU No 10 Tahun 1998 yang mengatur tentang Perbankan dan UU No 21 Tahun 2008 yang mengatur tentang Perbankan Syariah, UU No. 10 tahun 1998 dapat dikatakan lex generalis dan UU No 21 tahun 2008 dapat dikatakan sebagai lex spesialis, dengan demikian jika dalam kedua undang-undang tersebut ada pengaturan yang berbeda mengenai suatu hal maka bagi bank syariah harus digunakan UU No 21 Tahun 2008.

\section{Penutup}

\section{A. Simpulan}

1. Metoda/Bentuk penyelesaian sengketa perbankan syariah menurut UU No 3 Tahun 2006 dan UU No. 21 Tahun 2008 secara prinsip dilakukan melalui litigasi ke pengadilan dalam lingkungan Peradilan Agama dan Peradilan Umum, namun dapat pula dilakukan melalui proses nonlitigasi, yakni melalui

17 Abdul Ghofur Anshori, "Perbankan Syariah di Indonesia", Cet I, (Yogyakarta: Gajah Mada University Press, 2007 ), hal. 110. 
musyawarah,mediasi perbankan, Basyarnas atau arbitrase lain dan alternatif penyelesaian sengketa dengan ketentuan tidak bertentangan dengan syariah Islam.

2. Asas lex posteriorie derogat lex priori dan asas lex specialis derogat lex generalis tidak dapat digunakan dalam Choice of Forum antara Peradilan Agama dan Peradilan umum dalam penyelesaian sengketa perbankan syariah. Hal ini dikarenakan kedua undang-undang tersebut masih berlaku efektif, sehingga tidak ada undang-undang yang lama dan tidak ada pula undangundang yang baru dan karena kedua undang-undang tersebut mengatur hal yang berbeda, tidak ada undang-undang yang bersifat umum dan tidak ada pula undang-undang yang bersifat umum.

\section{B. Saran}

1. Prinsip syariah dalam operasional perbankan syariah bersifat mutlak. Oleh karena sesuatu yang bersifat mutlak tidak bisa ditawar lagi. Dengan demikian semua pihak yang terlibat dalam kegiatan perbankan syariah harus menguasai hukum Islam, khususnya di bidang perbankan.

2. Adanya choice of forum antara dua badan peradilan yang sederajat (Peradilan Agama dan Peradilan Umum) dalam penyelesaian sengketa perbankan syariah dapat menimbulkan disparitas putusan yang pada akhirnya menimbulkan ketidakpastian hukum oleh karena itu harus dihilangkan. 


\section{Daftar Pustaka}

Adolf, Huala dan A. Chandrawulan, Masalah-masalah Hukum dalam Perdagangan International, Jakarta : PT.Raja Grafindo Persada, 1994.

Anshori, Abdul Ghofur. Perbankan Syariah di Indonesia, Cet I, Yogyakarta : Gajah Mada University Press, 2007.

Basarah, Moch. Mengenal Arbitrase Nasional dan Internasional, Bandung: Fakultas Hukum, Unisba, 2008.

Darus Badrulzaman, Mariam. Kompilasi Hukum Perikatan, Bandung: Citra Aditya Bhakti, 2001.

Departemen Pendidikan dan Kebudayakan, Kamus Besar Bahasa Indonesia, Edisi ketiga Jakarta: Balai Pustaka, 2001.

Echols, John M dan Hassan Shadily, Kamus Inggris Indonesia (An EnglishIndonesia Dictionary), Jakarta: PT. Gramedia, 2005.

Fuady, Munir. Hukum Kontrak dari Sudut Pandang Hukum Bisnis, Bandung: Citra Aditya Bakti, 2007.

Joni Emerzon, Joni. Alternatif Penyelesaian Sengketa di Luar Pengadilan, Jakarta: Gramedia Pustaka Utama.

Marwan, M. dan Jimmy. P. Kamus Hukum (Dictionary of Law Complete Edition), Surabaya: Reality Publisher,2009.

Mutaqin, Dadan. "Penyelesaian Sengketa Perbankan Syariah di Luar Lembaga Peradilan", Varia Peradilan No. 26 (Januari 2008), Ikahi, Jakarta: 57

Salim H.S. Hukum Kontrak: Teori dan Teknik Penyusunan Kontrak, Jakarta: Sinar Grafika,2004.

Subekti, R. Arbitrase Perdagangan, Bandung: Binacipta, 1992.

Sutadi, Mariana "Pendalaman Materi Mediasi di Pengadilan", Bandung, 22 Nopember 2008.

Suyuti, Wildan. "Kapita Selekta Perbankan Syariah Menyongsong Berlakunya UU No.3 tahun 2006 tentang Perubahan UU No.7 Tahun 1989", Pusdiklat Teknis Peradilan Balitbang Diklat Kumdil MA-RI, Jakarta, 2008.

Syahdaeni, Remy. Kebebasan Berkontrak dan perlindungan yang Seimbang bagi Para Pihak dalam Perjanjian Kredit Bank di Indonesia, Jakarta: Institut Bankir Indonesia, 1993. 
424 Jurnal Hukum dan Pembangunan Tahun ke-40 No.3 Juli-September 2010

Umar Farouk, Peri. Sejarah Hukum Perbankan Syariah di Indonesia, download 04-09-2005. 